\title{
Evaluation of Petroleum Hydrocarbons Contamination in Soils and Groundwater Using Electrical Resistivity and Hydrochemical Methods-Case Study: Ayetoro, Osogbo Southwestern Nigeria
}

\author{
Mutiu A. Fakunle ${ }^{1 *}$, Muhydeen A. Ibraheem², Wasiu B. Agbaje ${ }^{3}$ and Luqman A. Abidoye \\ ${ }^{* 1}$ Department of Physics, Osun State University, Osogbo, Nigeria \\ E-mail: mutiu.fakunle@uniosun.edu.ng; fakunlemutiu2107@gmail.com \\ ${ }^{2}$ Department of Physics, Osun State University, Osogbo, Nigeria \\ E-mail: ibraheemmuhydeen1@gmail.com \\ ${ }^{3}$ Department of Chemical Sciences, Osun State University, Osogbo, Nigeria \\ E-mail: wasiu.agbaje@uniosun.edu.ng \\ ${ }^{4}$ Department of Chemical Engineering, Osun State University, Osogbo, Nigeria \\ E-mail: abidoye.luqman@uniosun.edu.ng \\ *Corresponding author \\ Received 23 Dec 2020, Revised 16 Apr 2021, Accepted 21 Apr 2021, Published May 2021 \\ DOI: https://dx.doi.org/10.4314/tjs.v47i2.15
}

\begin{abstract}
The presence of Petroleum Hydrocarbons (PHCs) in hand-dug wells has become a concern to the residents of Ayetoro area, Osogbo. Consequently, the detection of PHCs was evaluated using, nine Vertical Electrical Soundings (VES) and 2D electrical resistivity tomography surveys. Soil samples collected were analyzed for porosity and permeability. Hand-dug well water samples were screened for PHCs. VES revealed that second layer had high apparent resistivity of $14415.0 \Omega \mathrm{m}$, indicating presence of PHCs that had penetrated to maximum depth of $19.1 \mathrm{~m}$. The highest resistivity of the control points was $48.0 \Omega \mathrm{m}$, indicating absence of PHCs. The $2 \mathrm{D}$ resistivity revealed highest value of $3622 \Omega \mathrm{m}$ and had migrated to a depth of $10.0 \mathrm{~m}$. The porosity $(0.40)$ and permeability $\left(6.87516 \times 10^{-4} \mathrm{~cm} / \mathrm{s}\right)$ were typical of silty clay which allowed passage of PHCs. Hydro-chemical analysis indicated presence of PHCs $(0.50-11.00 \mathrm{mg} / \mathrm{L})$. The study has established presence of PHCs in soils and hand-dug wells.
\end{abstract}

Keywords: Petroleum Hydrocarbons, Soil, Groundwater, Electrical resistivity tomography

\section{Introduction}

Groundwater represents the water that is available within the subsurface. This water becomes useful to both living and non-living things when tapped. Living things (animals and human beings) use these natural resources for drinking and domestic purposes. The contamination of soil and water can occur or set in when external substances such as petroleum hydrocarbons, petrochemical effluents, poorly treated wastewater from oil refineries, chemicals used for agricultural purposes are added to them. Petroleum hydrocarbons though a source of energy that dominates other sources of energy can be added to soils and groundwater due to leakage of buried and overhead tanks and pipes as well as when there are accidental spills during transportation and disposal. The presence of all these important products in soils can degrade land, contaminate surface and groundwater thereby pose significant threats to human health and ecological receptors (Ite et al. 2013). It was reported by Obida et al. (2018) that 
between 2007 and 2015, $66 \mathrm{~km}^{2}$ of water bodies were contaminated by PHCs, and that $29 \%$ of the population within the spill radius have faced acute (short term) or chronic (longterm) health consequences. Ordinioha and Brisibe (2013) reported that petroleum hydrocarbons spills could lead to $60 \%, 40 \%$, and $30 \%$ reduction in household food security, the crude protein content of cassava and ascorbic acid content of vegetables, respectively. Clinton et al. (2009) also evaluated, analyzed, and indicated that the total petroleum hydrocarbons (TPHCs) in a water sample at the well-head stations, in Niger Delta were above the $10 \mathrm{mg} / \mathrm{L}$ tolerance level recommended by the Federal Ministry of Environment in Nigeria. Clinton et al. (2009) and Yakubu (2017) described Total Petroleum Hydrocarbons [TPHCs] as the mixture of organic compounds found or derived from crude oil that have the ability to be toxic. These compounds have limited solubility thereby forming individual liquid phases known as non-aqueous phase liquids [NAPLs]. NAPLs are generally divided into two individual groups according to their specific gravity-less dense than water called Light NAPLs (LNAPLs] and denser than water called Dense NAPLs (DNAPLs). Gravitational and capillary forces aided the vertical movement of the spilled and leaked PHCs from the source point to the soils and groundwater. Lateral migration of the spilled and leaked PHCs is also aided by the capillary. The entering and diffusion of all these important liquids from the source point to the soils and groundwater could be a result of flooding. The spilled and leaked PHCs in the soils are broken down by organisms (Kponee et al. 2015) into smaller fractions, some may evaporate into the atmosphere, while others may stay in the soils for a longer time and be broken down by other organisms that are present in the soil causing hazardous health effects Ite et al. (2013). Once the PHCs are released into the soil, depending on the chemical properties, the complex PHCs mixtures get separated into individual compounds (polycyclic aromatic hydrocarbons
(Ite et. al. 2013) and other Volatile Organic compounds (VOCs) such as benzene, toluene, ethylbenzene and xylenes [BTEX] (Rittmann 1995, Mohamadi 2015). BTEX are very mobile, highly volatile, and are easily leached to the groundwater than their counterpart of higher molecular weight (Kponee et al. 2015, Lindén and Pålsson 2013). Other site-specific factors that aid in the leaching of the leaked or spilled PHCs to groundwater include the amount of spilled or leaked PHCs, climate, terrain, vegetation, and soil inherent properties (Holdway 2002, Kponee et al. 2015). The presence of the PHCs in soils and groundwater affects their resistivity. The electrical resistivity method was used in this research since the resistivity of rocks is strongly influenced by the presence of groundwater which acts as an electrolyte especially in a porous medium and since the minerals that form the matrix of rock are generally poorer conductors than groundwater. The conductivity of the rock is proportional to the conductivity of the groundwater which is quite variable because it depends on the concentrations and the types of dissolved salts it contains. Anomalies arise when a good or poor conductor is added (leachate) or mixed with the groundwater the rock contains. But when petroleum hydrocarbons that are poor conductors are added to the soils and groundwater, they cause an increase in the resistivity of these natural resources compared to that in which water is purely the pore fluid. Petroleum hydrocarbons when present in pore water cause its resistivity to increase to a minimum level. This study focused on the analysis and detection of the contamination of these two natural resources by Petroleum Hydrocarbons (PHCs) using two types of arrays-Schlumberger and Dipoledipole arrays the vertical and lateral extent of the migration of PHCs resistivity, respectively (Habberjam and Watkins 1967, Barker 1981, Bhattacharya and Patra 1968).

\section{Study Site Description}

Ayetoro, a residential area with population of about 5,000 people and covering an estimate of 
15,000 acres of land, is in the southwestern part of Nigeria. It lies between latitudes N07 ${ }^{\circ} 47^{\prime}$ 13.692" and N07 46' 55.398" and longitudes E04 ${ }^{\circ} 33^{\prime}$ 52.686" and E04 ${ }^{\circ} 33^{\prime} 45.246^{\prime \prime}$. Ayetoro, like other parts of southwestern Nigeria, lies within the tropical rain forest that is characterized by two prominent seasons: the wet season and the dry seasons that are usually experienced and span between April and October, and between November and March, respectively of each year. The study area is easily accessible due to the presence of footpaths and tarred major and minor roads.

\section{Study Site Geology}

Geologically, Ayetoro is underlain by the Precambrian basement complex rocks typical of southwestern Nigeria (Rahaman 1976). Gneiss and migmatite undifferentiated and schist pegmatite are the main lithological units obtainable in the study area with gneiss and migmatite undifferentiated, being the dominant one (see Figure 1). The classification of the geology of the study area was based on the porosity and permeability due to rock debris after weathering. The gneisses and granite weather into higher permeability sandy clay, clayey sand, and sand with higher groundwater discharge capacity, while schist pegmatite fractured excellently to increase permeability (Yenne et al. 2015).

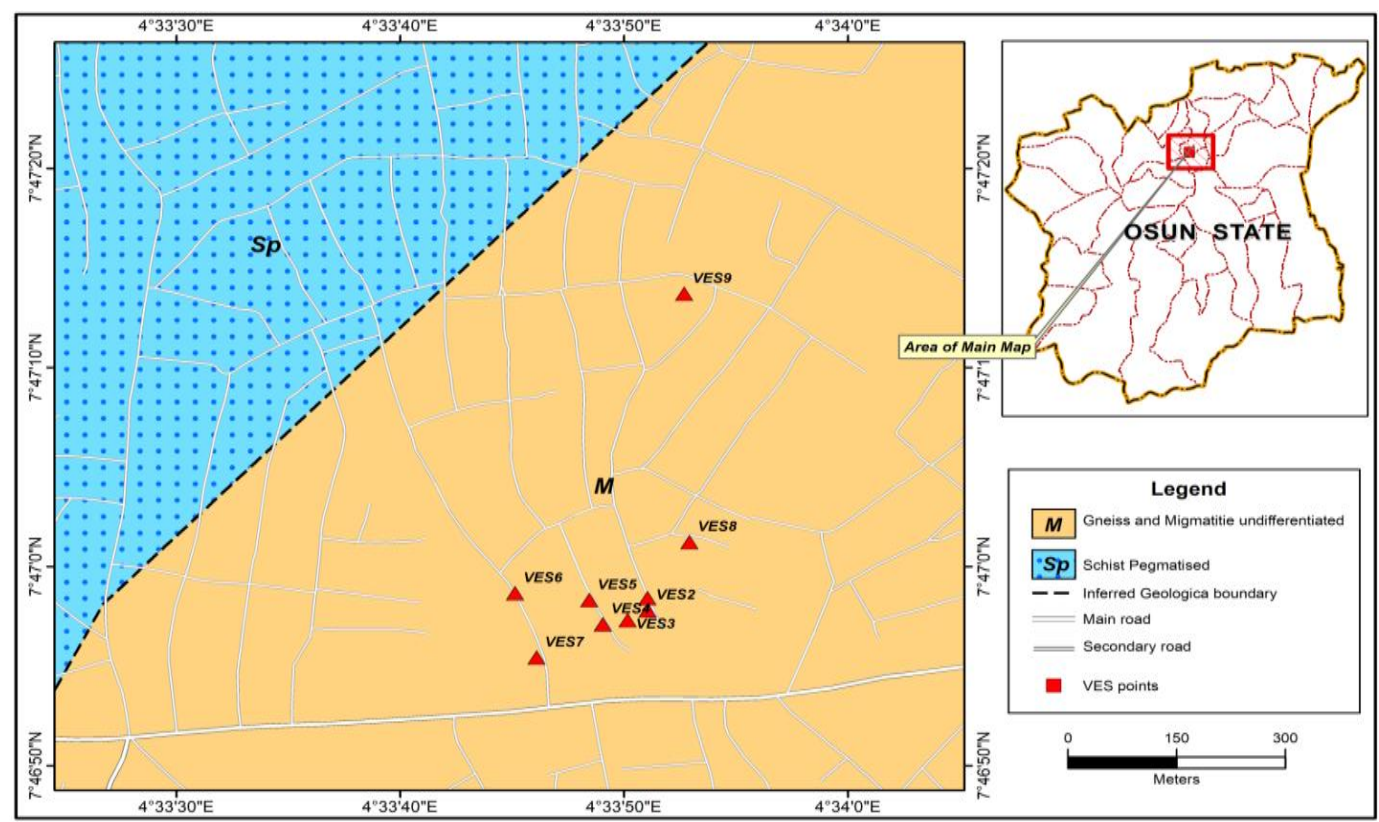

Figure 1: Geological map of Ayetoro (Adapted after Grant 1971).

\section{Materials and Methodology VES data acquisition}

Due to limited space caused majorly by residential buildings and having avoided house obstruction, seven (7) different Vertical Electrical Sounding (VES) stations were probed using Schlumberger electrode configuration in the study site, while two different VES points (VES 8 and 9) which were $500.0 \mathrm{~m}$ and $1200.0 \mathrm{~m}$, respectively from the reference point of the study site were also probed to serve as controls. Global Positioning System (GPS) was used to record the location and position of each VES point. Using DDR-3 resistivity meter, two current stainless-steel electrodes A and B were used to inject current 
into the subsurface. While the resulting potential differences were measured using two different stainless-steel electrodes $\mathrm{M}$ and $\mathrm{N}$. The current electrodes were expanded from a minimum current electrode spacing $(\mathrm{AB} / 2)$ of $1.0 \mathrm{~m}$ to a maximum of $120.0 \mathrm{~m}$. The apparent resistivity of the subsurface was obtained using

$$
\rho_{a}=\mathrm{K} \frac{\Delta V}{I}
$$

where;

$$
\mathrm{K}=\frac{\pi}{2}\left[\frac{(A B / 2)^{2}-(\mathrm{MN} / 2)^{2}}{M N}\right]
$$

is the geometric factor, $\mathrm{AB}$ and $\mathrm{MN}$ being the distances between the current electrode pair and potential electrode pair, respectively. The position and location of each VES point were recorded by using a Geographic Positioning System (GPS) meter. The field data obtained was plotted and iterated using IP12WIN computer software to reveal the true resistivity of different layers present and their thicknesses.

\section{Electrical resistivity tomography data acquisition and analysis}

To employ electrical resistivity tomography, the electrodes spacing between current and potential electrodes has to be same. In this study, Dipole-dipole array was used where the spacing (a) between two current electrodes $(\mathrm{AB})$ and potential electrodes $(\mathrm{MN})$ was the same. Current was injected into the ground and the resulting potentials developed were measured, then apparent resistivity $\rho_{a}$ was calculated using

$$
\begin{aligned}
& \rho_{a}=\pi \mathrm{R} \mathrm{k} \\
& \text { where k=a n }(\mathrm{n}+1)(\mathrm{n}+2)
\end{aligned}
$$

This procedure was then repeated for measurement with different spacing ranging from $2 \mathrm{a}$ to na. In each case, apparent resistivity was calculated. The calculated apparent resistivity data helped to build up a pseudo section beneath the surveyed profile. To be able to detect the presence of PHCs in fractured and weathered layer, 2D electrical resistivity tomography surveys were conducted along two profile lines at different points in the study area using DDR-3 resistivity meter. Each of the profile length was $100.00 \mathrm{~m}$ and oriented in the east-west directions. Measurements were made in sequence of increasing offset distances spacing along the profile lines ranging from 5.0 $\mathrm{m}$ to $100.0 \mathrm{~m}$ using four stainless steel electrodes. The electrodes were moved in a leapfrog manner to achieve a continuous horizontal coverage of the subsurface. The spacing (a) of $5.0 \mathrm{~m}$ was chosen for possible detection of PHCs pathways and or structures till $25.0 \mathrm{~m}$ depth which could be considered satisfactory for the required information. DIPROWIN modeling software was used to interpret and invert the apparent resistivity $\left(\rho_{a}\right)$ section. The inversion process is based on finite element method. The inversion program divides the subsurface into a number of small rectangular prisms and attempts to determine the resistivity values of the model prisms directing toward minimizing the difference between the calculated and the observed apparent resistivity values. The results obtained from the processing of the field data are presented as 2D resistivity structures, pseudo section and theoretical pseudo sections.

\section{Determination of permeability and porosity}

To determine how permeable and porous the soils in the study area were, a hand digger was used to evacuate the soil at a depth of $1.0 \mathrm{~m}$. The evacuated soil samples were collected and put in a polythene bag. A total of five (5) soil samples were collected, labeled and transported to the Soil Laboratory of the Department of Civil Engineering, Osun State University for the determination of permeability and porosity. The permeability of the soil was calculated from

$$
K=\frac{\mathrm{QL}}{\mathrm{Ah}}
$$


Where: $Q=$ Discharge $=\mathrm{v} / \mathrm{t}, \mathrm{t}=$ time, $\mathrm{L}=$ length of the specimen, $A=\pi r^{2}=$ Area of specimen and $\mathrm{h}=$ height $\left(\mathrm{h}_{2}-\mathrm{h}_{1}\right)$.

The porosity $(\phi)$ was obtained using

Porosity $(\phi)=\frac{\text { Used water }}{\text { Total volume of soil }} \times 100$

Where porosity was reported in percentage $(\%)$ and Used water $=$ Initial volume - Final volume.

\section{Water samples collection and analysis}

A total of eleven water samples were collected from eleven hand-dug wells in 1 liter sampling bottles which were thoroughly washed with soap, rinsed with deionized water and finally rinsed with $1 \mathrm{M}$ trioxonitrate $(\mathrm{V})$ acid $\left(\mathrm{HNO}_{3}\right)$. The bottles were rinsed with each of the water samples before being filled. Out of these eleven water samples, one was collected from a well that was at a distance of $1200.0 \mathrm{~m}$ from the reference point and served as the control. These samples were preserved in a refrigerator prior to analysis the following day before the commencement of the analysis. The location, position, and elevation of each well were recorded using Global Positioning System (GPS). Another physical parameter that was taken and recorded was the depth to water table level of each well. The analysis of each sample was done following the prescription of American Public Health Association (APHA 2005). The distance of each well to the reference point was measured and recorded.

\section{Results and Discussions}

\section{VES data results and discussion}

Table 1 presents the results of various VES analyses, the distance of each VES point, the type of log-log plots obtained from the VES analysis, and the lithology of the layer present in the study area. The log-log plots of the VES against current electrode spacing revealed two distinct curve types-AA and HA, with the AA curve type being the most prevalent and prominent, while the HA curve is obtainable at the control. Figures 2, 3 and 4 show the typical curves of these two types. These curves reveal three and four geoelectric layers. The first layer is the topsoil with resistivity values ranging from 2.08 to $62.8 \Omega \mathrm{m}$ typical of the silty or clayey material layer, while the thickness of this layer varied from 0.229 to $4.010 \mathrm{~m}$. This thin overburden layer is porous which aids the petroleum hydrocarbons sink easily into the subsurface. The second layer, a weathered layer has resistivity values ranged from 14415.0 to $10.5 \Omega \mathrm{m}$. The high resistivity values recorded are attributed to the presence of petroleum hydrocarbons (non-conductors) which decrease as the distance of the VES points increases. The decrease in resistivity values in this layer as the distance increases is a result of the decrease in the reduction of the petroleum hydrocarbons in this layer. The least resistivity value, $10.5 \Omega \mathrm{m}$ at VES 7 was recorded at a distance of $350.7 \mathrm{~m}$ an indication that the PHCs decrease in value in water. The depth of penetration of PHCs in this layer ranged from 5.29 to $19.1 \mathrm{~m}$. The resistivity values of the second layer of the control ranged from 5.16 to $48.0 \Omega \mathrm{m}$. These low resistivity values recorded indicated the absence of PHCs and could not be the host of the contaminants. The third layer of the study area is a basement whose resistivity values varied from 47.9 to $30903.0 \Omega \mathrm{m}$, while that of the control ranged from 1540 to $4204 \Omega \mathrm{m}$. 
Fakunle et al. - Evaluation of petroleum hydrocarbons contamination in soils and groundwater

Table 1: Curve types, apparent resistivity, thickness of the various VES and lithology

\begin{tabular}{|c|c|c|c|c|c|c|c|}
\hline $\mathrm{S} / \mathrm{N}$ & $\begin{array}{c}\text { VES } \\
\text { distance } \\
(\mathrm{m})\end{array}$ & Coordinate & $\begin{array}{l}\text { Curve } \\
\text { type }\end{array}$ & $\begin{array}{l}\text { Apparent } \\
\text { resistivit } \\
\mathrm{y}(\Omega \mathrm{m})\end{array}$ & $\begin{array}{c}\text { Thickne } \\
\text { ss } \\
(\mathrm{m})\end{array}$ & $\begin{array}{l}\text { Depth } \\
\text { (m) }\end{array}$ & Lithology \\
\hline \multirow{3}{*}{$\begin{array}{c}\text { VES } \\
1\end{array}$} & \multirow[t]{3}{*}{5.0} & \multirow{3}{*}{$\begin{array}{l}\mathrm{N}^{\circ} 7^{\circ} 46^{\prime} 58.416^{\prime \prime} \\
\mathrm{E}^{\prime} 4^{\circ} 33^{\prime} 51.042^{\prime \prime}\end{array}$} & \multirow{3}{*}{ AA } & 2.08 & 0.322 & 0.322 & Clayed topsoil \\
\hline & & & & 14415 & 11.9 & 12.2 & $\begin{array}{c}\text { Weathered } \\
\text { layer }\end{array}$ \\
\hline & & & & 47.9 & & & Basement \\
\hline \multirow{3}{*}{$\begin{array}{c}\text { VES } \\
2\end{array}$} & \multirow{3}{*}{13.2} & \multirow{3}{*}{ 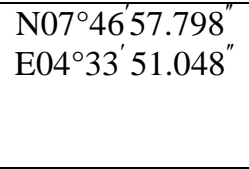 } & \multirow[t]{3}{*}{ AA } & 3.07 & 0.306 & 0.306 & Clayed topsoil \\
\hline & & & & 9040 & 6.4 & 6.71 & $\begin{array}{l}\text { Weathered } \\
\text { layer }\end{array}$ \\
\hline & & & & 2595 & - & - & Basement \\
\hline \multirow{3}{*}{$\begin{array}{c}\text { VES } \\
3\end{array}$} & \multirow[t]{3}{*}{22.1} & \multirow{3}{*}{$\begin{array}{l}\mathrm{N}^{0} 7^{\circ} 46^{\prime} 57.306^{\prime \prime} \\
\mathrm{E}^{\circ} 4^{\circ} 33^{\prime} 50.148^{\prime \prime}\end{array}$} & \multirow{3}{*}{ AA } & 36.4 & 4.01 & 4.01 & Topsoil \\
\hline & & & & 365 & 19.1 & 23.1 & $\begin{array}{c}\text { Weathered } \\
\text { layer }\end{array}$ \\
\hline & & & & 2598 & - & - & Basement \\
\hline \multirow{3}{*}{$\begin{array}{c}\text { VES } \\
4\end{array}$} & \multirow[t]{3}{*}{65.3} & \multirow{3}{*}{$\begin{array}{l}\text { N07 } 46^{\prime} 57.096^{\prime \prime} \\
\text { E04 }^{\circ} 33^{\prime} 49.044^{\prime \prime}\end{array}$} & \multirow{3}{*}{ AA } & 27 & 0.229 & 0.229 & Topsoil \\
\hline & & & & 244 & 8.14 & 8.37 & $\begin{array}{c}\text { Weathered } \\
\text { layer }\end{array}$ \\
\hline & & & & 30903 & - & - & Basement \\
\hline \multirow{3}{*}{$\begin{array}{c}\text { VES } \\
5\end{array}$} & \multirow{3}{*}{85.0} & \multirow{3}{*}{ 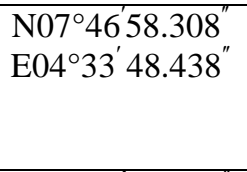 } & \multirow{3}{*}{ AA } & 11.5 & 1.99 & 1.99 & Topsoil \\
\hline & & & & 58.0 & 16.8 & 18.8 & $\begin{array}{c}\text { Weathered } \\
\text { layer }\end{array}$ \\
\hline & & & & 4841 & - & - & Basement \\
\hline \multirow{3}{*}{$\begin{array}{c}\text { VES } \\
6\end{array}$} & \multirow[t]{3}{*}{315.2} & \multirow{3}{*}{$\begin{array}{l}\mathrm{N}^{\circ} 7^{\circ} 46^{\prime} 58.656^{\prime \prime} \\
\mathrm{E} 04^{\circ} 33^{\prime} 45.12^{\prime \prime}\end{array}$} & \multirow{3}{*}{ AA } & 21 & 2.18 & 2.18 & Topsoil \\
\hline & & & & 37.6 & 5.29 & 8.09 & $\begin{array}{c}\text { Weathered } \\
\text { layer }\end{array}$ \\
\hline & & & & 701 & - & - & Basement \\
\hline \multirow{3}{*}{$\begin{array}{c}\text { VES } \\
7\end{array}$} & \multirow[t]{3}{*}{350.7} & \multirow{3}{*}{$\begin{array}{l}\text { N07 } 46^{\prime} 55.422^{\prime \prime} \\
\text { E04 }^{\circ} 33^{\prime} 46.092^{\prime \prime}\end{array}$} & \multirow{3}{*}{ AA } & 2.28 & 0.314 & 0.314 & Topsoil \\
\hline & & & & 10.5 & 6.08 & 6.4 & $\begin{array}{c}\text { Weathered } \\
\text { layer }\end{array}$ \\
\hline & & & & 290 & - & - & Basement \\
\hline \multirow{3}{*}{$\begin{array}{c}\text { VES } \\
8\end{array}$} & \multirow{3}{*}{500.0} & \multirow{3}{*}{$\begin{array}{l}\text { N07 } 47^{\prime} 1.224^{\prime \prime} \\
\text { E04 } 33^{\prime} 52.914^{\prime \prime}\end{array}$} & & 62.8 & 0.704 & 0.704 & Topsoil \\
\hline & & & HA & 5.16 & 1.25 & 1.96 & $\begin{array}{c}\text { Weathered } \\
\text { layer }\end{array}$ \\
\hline & & & & 4204 & - & - & Basement \\
\hline VES & & N07047 $13.692^{\prime \prime}$ & & 25.7 & 0.357 & 0.357 & Topsoil \\
\hline 9 & 1200.0 & 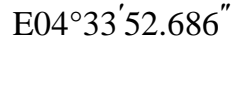 & HA & 48 & 0.769 & 1.13 & $\begin{array}{c}\text { Weathered } \\
\text { layer }\end{array}$ \\
\hline & & & & 2.6 & 1.5 & 2.62 & Fracture \\
\hline & & & & 1540 & - & - & Basement \\
\hline
\end{tabular}


Tanz. J. Sci. Vol. 47(2), 2021

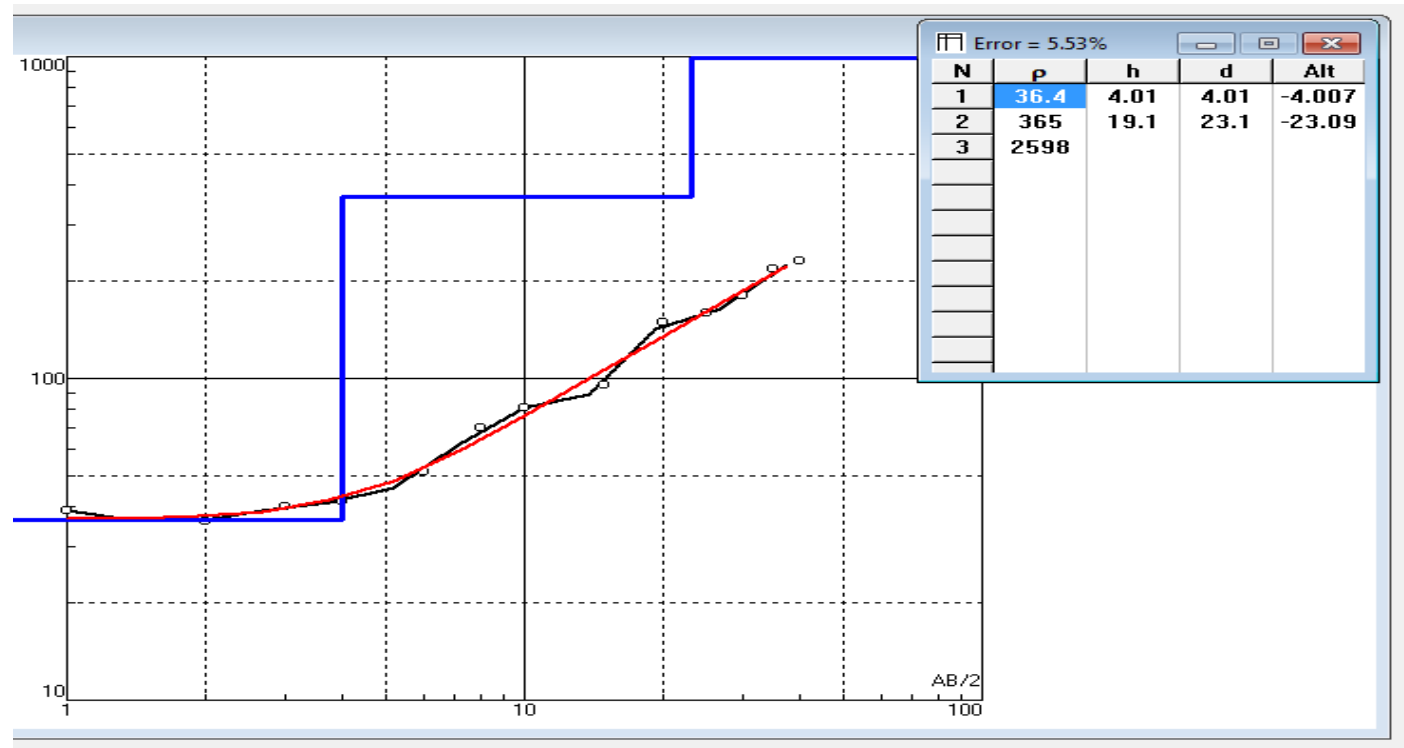

Figure 2: Typical log-log plot of VES 3.

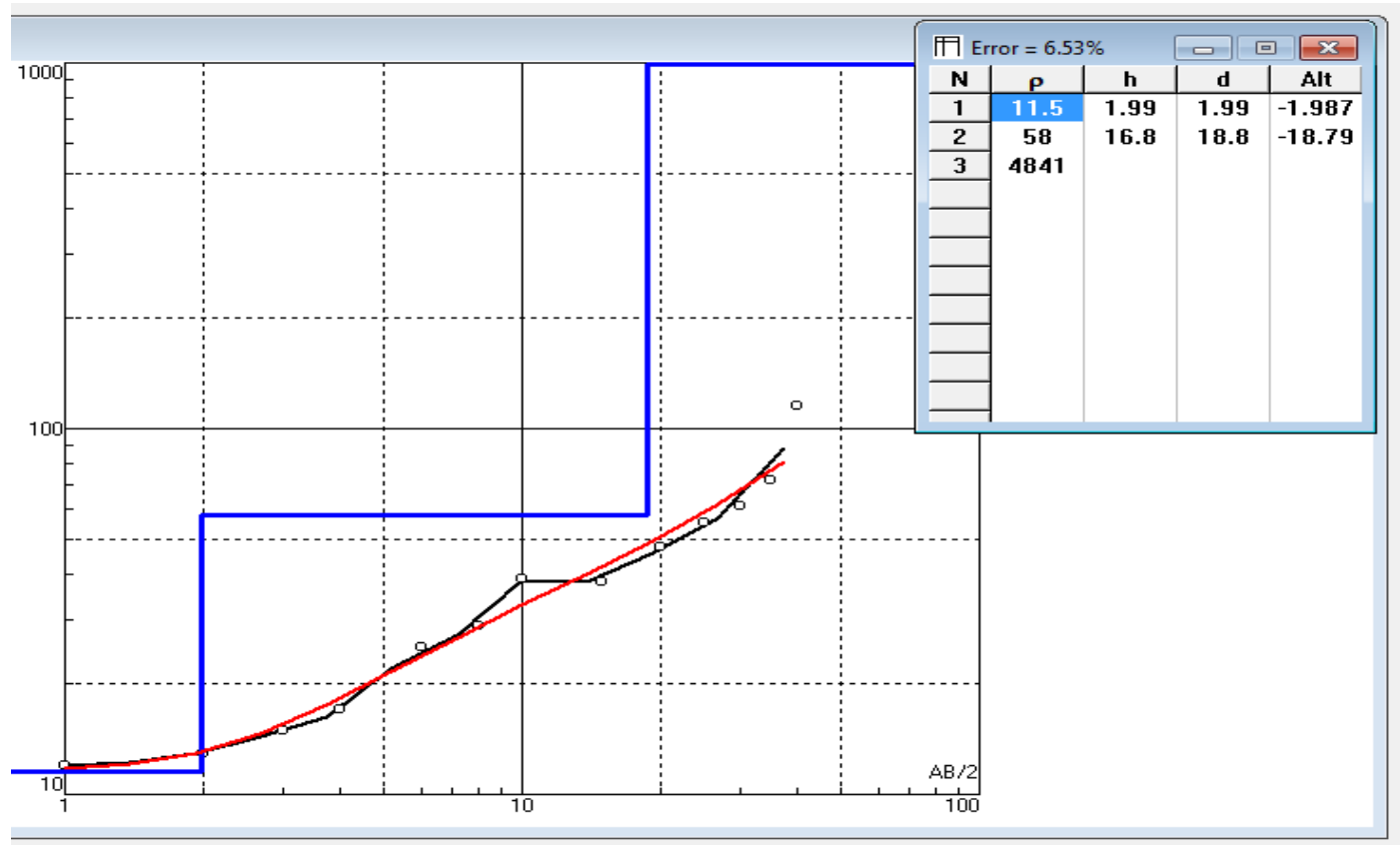

Figure 3: Typical log-log plot of VES 5. 
Fakunle et al. - Evaluation of petroleum hydrocarbons contamination in soils and groundwater

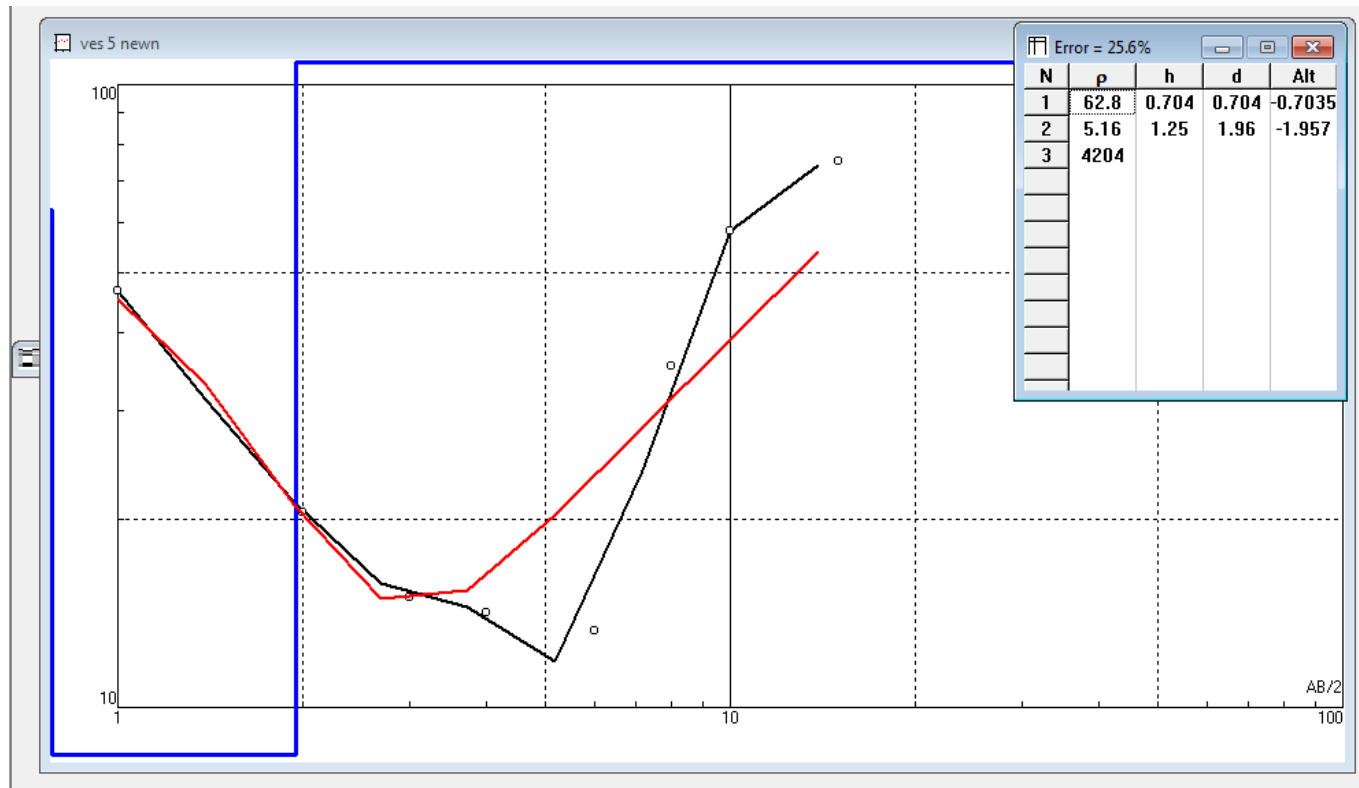

Figure 4: Typical log-log plot of control VES 8.

2D Resistivity tomography survey results and discussion

The results of the $2 \mathrm{D}$ inverted resistivity sections obtained from the study site are indicated in Figures 5 and 6 . These two figures indicated both the pseudo section of the field and theoretical data, as well as the 2D resistivity structure. The results of the $2 \mathrm{D}$ inverted resistivity sections of the study site delineated major subsurface layers present, which are the topsoil, weathered basement, and basement rock and are represented by the blue, green, yellow, and red or purple color. The topsoil (blue color) is highly porous, the weathered material (green), is permeable and likely to host the Petroleum Hydrocarbons (PHCs). The yellow color is the fair rock which is not permeable, while red or purple color represents good rock or basement rock. The results of the 2D inverted resistivity of the study site revealed that the overburden thickness varied from 1.0 . to $10.0 \mathrm{~m}$ as represented by the blue color and its resistivity values ranged from 72.0 to $400.0 \Omega \mathrm{m}$. The green portion is between the overburden and the basement and has resistivity values ranging from $940.0 \Omega \mathrm{m}$ to $3622.0 \Omega \mathrm{m}$. This layer is the host of PHCs. The results of the 2D resistivity structured indicated variations in resistivity values from $72.0 \Omega \mathrm{m}$ to $350.0 \Omega \mathrm{m}$ at the depth range of $0.0 \mathrm{~m}$ to $10.0 \mathrm{~m}$ typical of porous material. As indicated by the pseudo section, petroleum hydrocarbons are located at the depth of $5.0 \mathrm{~m}$ and are flowing on top of the basement rocks but fade away gradually at a deeper depth. However, its effect is not noticeable at $15.0 \mathrm{~m}$ depth. 

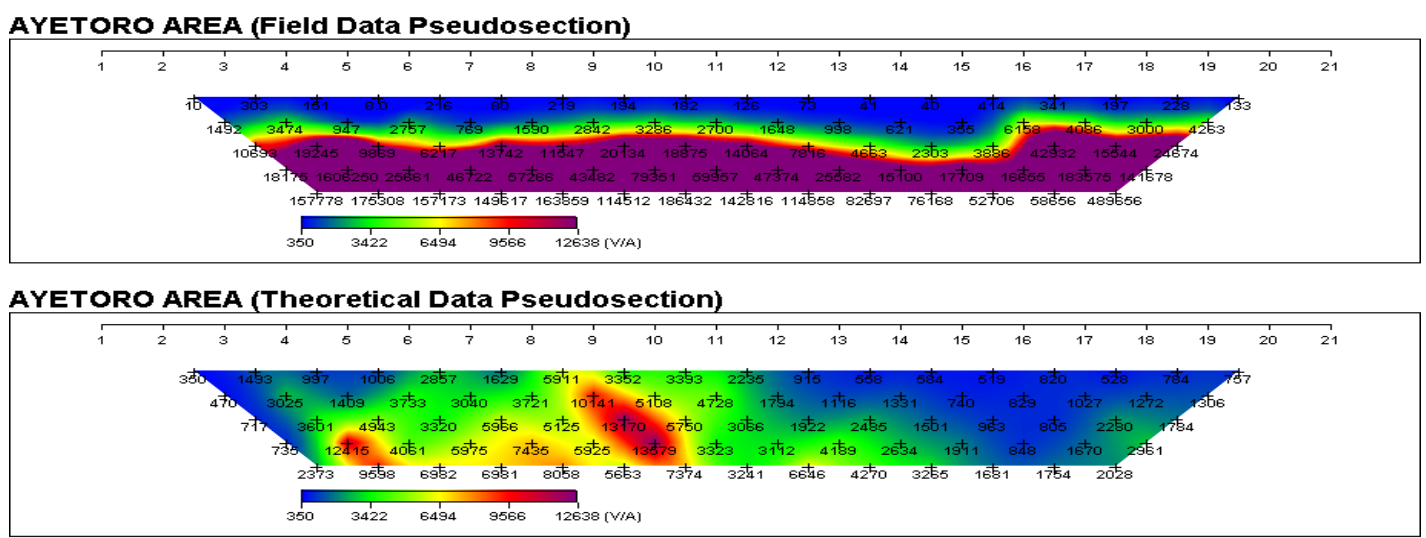

AYETORO AREA (2-D Resistivity Structure)

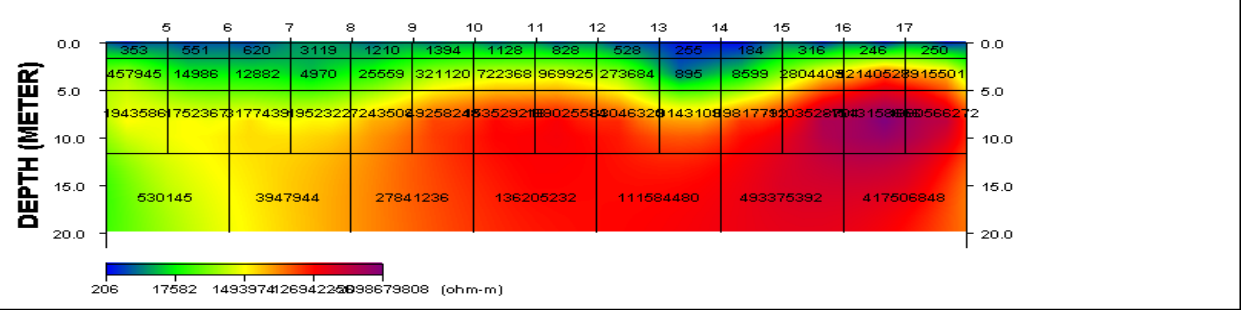

Figure 5: 2D Inversion results for Profile 1: (A) Field data pseudo section, and (B) Theoretical pseudo-section and (C) 2-D resistivity structure.
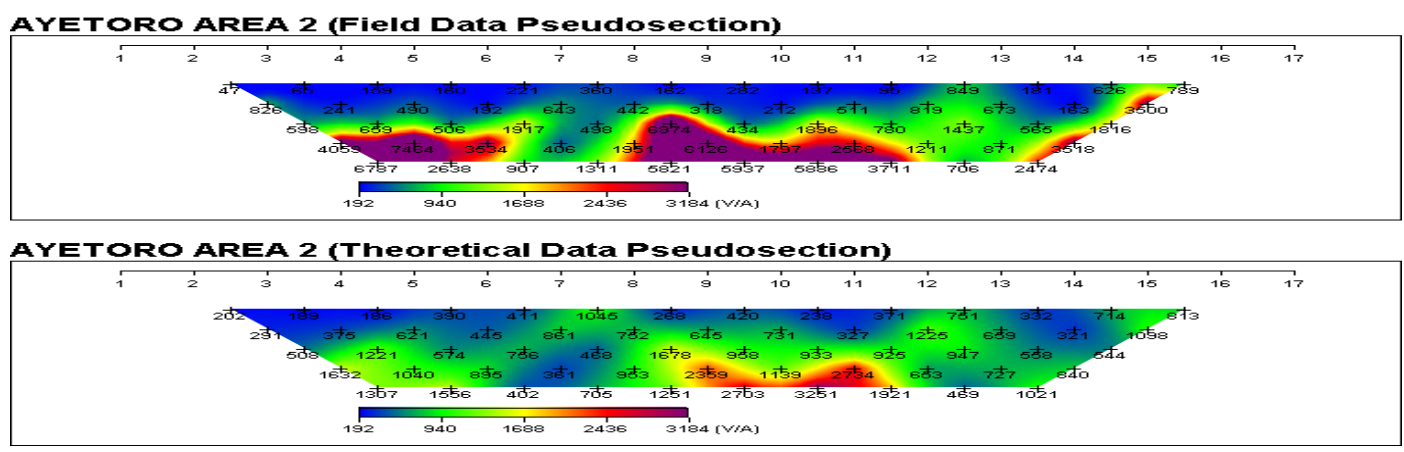

\section{AYETORO AREA 2 (2-D Resistivity Structure)}

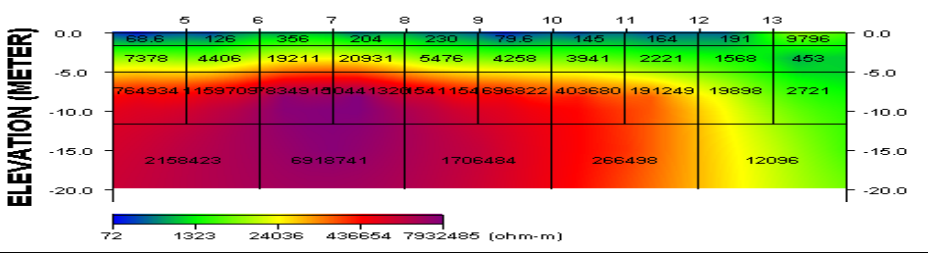

Figure 6: 2D Inversion results for Profile 2: (A) Field data pseudo section, and (B) Theoretical pseudo-section and (C) 2-D resistivity structure. 
Results and discussions of the porosity and coefficient of permeability test

The results of the laboratory test for porosity $(\varnothing)$ and coefficient of permeability (K) of the soil samples are presented in Table 2. The average value of $\mathrm{K}$ is $6.87516 \times 10^{-4} \mathrm{~cm} / \mathrm{s}$; the characteristics of silty clay thus allow the flow of PHCs plume to the soil and groundwater in the study area. The values of coefficients of permeability obtained may be influenced by (1) textural properties (i.e., pore size/ grain size, grain size distribution, the shape of grains and packing of grains), (2) gas slippage, (3) amount distribution and type of clays, (4) type and amount of secondary porosity, (5) overburden pressure, (6) reactive fluids, and (7) highvelocity flow effects. The coefficient of permeability determined in this work was compared with the standard coefficient of permeability values of soil Evirgen et al. (2015). This showed that the host of the PHCs is composed of silty clay. The value of the porosity that was determined in the laboratory in this work was 0.4006 which was compared with the standard porosity values of soil de Castro et al. (2014). It showed that the porosity of the contaminant layer is low being silty clay.

Table 2: Soil analysis results

\begin{tabular}{|c|c|c|c|}
\hline Soil sample no & Location & Coefficient of permeability K (cm/s) & Porosity \\
\hline 1 & $\begin{array}{c}07^{\circ} 47^{\prime} 1.068^{\prime \prime} \\
04^{\circ} 33^{\prime} 50.052^{\prime \prime}\end{array}$ & $4.87942 \times 10^{-5}$ & 0.364 \\
\hline 2 & $\begin{array}{c}07^{\circ} 46^{\prime} 57.918^{\prime \prime} \\
04^{\circ} 33^{\prime} 49.572^{\prime \prime}\end{array}$ & $5.62673 \times 10^{-5}$ & 0.400 \\
\hline 3 & $0^{\circ} 46^{\prime} 57.972^{\prime \prime}$ & & 0.415 \\
\hline 4 & $04^{\circ} 33^{\prime} 47.052^{\prime \prime}$ & $6.51521 \times 10^{-5}$ & 0.412 \\
& $07^{\circ} 46^{\prime} 59.016^{\prime \prime}$ & $7.75310 \times 10^{-5}$ & 0.413 \\
\hline 5 & $04^{\circ} 33^{\prime} 45.246^{\prime \prime}$ & & \\
\hline Average & $07^{\circ} 46^{\prime} 55.398^{\prime \prime}$ & $9.60133 \times 10^{-5}$ & 0.4006 or \\
& $04^{\circ} 33^{\prime} 45.354^{\prime \prime}$ & & $4.006 \times 10^{-1}$ \\
\hline
\end{tabular}

\section{Results and discussion of water sample} analysis

Table 3 shows the results of the water samples analysis. The results indicated that all the water samples contained petroleum hydrocarbons except the control. Total petroleum hydrocarbons (TPHCs) levels of the samples ranged from 0.50 to $11.00 \mathrm{mg} / \mathrm{L}$. Water samples from wells 1 and 7 which were at a distance of 13.0 and $170.0 \mathrm{~m}$ respectively had concentration of approximately $11.00 \mathrm{mg} / \mathrm{L}$ which was the highest level of TPHCs recorded in the studied water samples. This level was higher than $10.0 \mathrm{mg} / \mathrm{L}$ which was the permissible limit of the Federal Ministry of Environment in Nigeria (FMEnv 1991). The value of Total Petroleum Hydrocarbons in the water sample from well 1 was $10.8 \mathrm{mg} / \mathrm{L}$. The value of TPHCs is higher here because of the suspected source of TPHCs leaking point. The higher level of the TPHCs in well 7 could be attributed to the fact that it was located at the bottom of the slope and that TPHCs flow follows the topography pattern of the environment. From the results of the water analysis, the concentrations of TPHCs decrease as the distance of each well from the suspected source increases except at distance $70.0 \mathrm{~m}$ (well 4) and $310.0 \mathrm{~m}$ (well 9) which might be done to the location of these wells along the slope. The presence of TPHCs is not noticeable in the control sample because the well is at a distance of $1200.0 \mathrm{~m}$. The lowest value of TPHCs $(0.5 \mathrm{mg} / \mathrm{L})$ was recorded at a distance of $350.0 \mathrm{~m}$; this is far away from the suspected point. 
Table 3: Water samples analysis results

\begin{tabular}{|c|c|c|c|c|c|c|}
\hline S/N & $\begin{array}{l}\text { Sample } \\
\text { code }\end{array}$ & $\begin{array}{l}\text { Water } \\
\text { table depth } \\
(\mathrm{m})\end{array}$ & Coordinate & $\begin{array}{l}\text { Distance from } \\
\text { the reference } \\
\text { point }(\mathrm{m})\end{array}$ & $\begin{array}{l}\text { Elevati } \\
\text { on (m) }\end{array}$ & $\begin{array}{l}\text { Concentration of } \\
\text { total petroleum } \\
\text { hydrocarbon } \\
\text { (mg/L) }\end{array}$ \\
\hline 1 & Well 1 & 1.7 & $\begin{array}{c}07^{\circ} 46^{\prime \prime} 57.798^{\prime \prime} \\
04^{\circ} 33^{\prime} 51.048^{\prime \prime}\end{array}$ & 13.0 & 339.0 & 10.8 \\
\hline 2 & Well 2 & 3.5 & $\begin{array}{l}07^{\circ} 46^{\prime} 57.426^{\prime \prime} \\
04^{\circ} 33^{\prime} 51.144^{\prime \prime}\end{array}$ & 15.0 & 336.0 & 6.50 \\
\hline 3 & Well 3 & 5.2 & $\begin{array}{c}07^{\circ} 46^{\prime} 59.484^{\prime \prime} \\
04^{\circ} 33^{\prime} 49.476^{\prime \prime}\end{array}$ & 62.0 & 343.0 & 5.30 \\
\hline 4 & Well 4 & 10.2 & $\begin{array}{c}07^{\circ} 46^{\prime} 57.918^{\prime \prime} \\
04^{\circ} 33^{\prime} 49.572^{\prime \prime}\end{array}$ & 70.0 & 336.0 & 7.50 \\
\hline 5 & Well 5 & 7.5 & $\begin{array}{c}07^{\circ} 47^{\prime} 0.228^{\prime \prime} \\
04^{\circ} 33^{\prime} 48.318^{\prime \prime}\end{array}$ & 83.0 & 336.0 & 4.25 \\
\hline 6 & Well 6 & 5.3 & $\begin{array}{l}07^{\circ} 46^{\prime} 59.766^{\prime \prime} \\
04^{\circ} 33^{\prime} 46.668^{\prime \prime}\end{array}$ & 160.0 & 336.0 & 3.25 \\
\hline 7 & Well 7 & 4.7 & $\begin{array}{c}07^{\circ} 47^{\prime} 1.824^{\prime \prime} \\
04^{\circ} 33^{\prime} 47.382^{\prime \prime}\end{array}$ & 170.0 & 342.0 & 11.0 \\
\hline 8 & Well 8 & 5.8 & $\begin{array}{l}07^{\circ} 46^{\prime} 57.936^{\prime \prime} \\
04^{\circ} 33^{\prime} 45.984^{\prime \prime}\end{array}$ & 300.0 & 331.0 & 1.05 \\
\hline 9 & Well 9 & 3.8 & $\begin{array}{l}07^{\circ} 46^{\prime} 59.160^{\prime \prime} \\
04^{\circ} 33^{\prime} 45.246^{\prime \prime}\end{array}$ & 310.0 & 340.0 & 6.05 \\
\hline 10 & Well 10 & 6.5 & $\begin{array}{l}07^{\circ} 46^{\prime} 56.598^{\prime \prime} \\
04^{\circ} 33^{\prime} 46.554^{\prime \prime}\end{array}$ & 350.0 & 331.0 & 0.50 \\
\hline 11 & Control & 6.9 & $\begin{array}{l}07^{\circ} 47^{\prime} 13.692^{\prime \prime} \\
04^{\circ} 33^{\prime} 52.686^{\prime \prime}\end{array}$ & 1200.0 & 342.0 & Nil \\
\hline
\end{tabular}

\section{Conclusion}

The results of the study have shown that the soil is permeable and porous that could allow the passage of the leaked and spilled PHCs through the soils to groundwater where the PHCs could mix, float, and sink into the groundwater. This is evident in the results of VES and 2D resistivity. The second layer considered showed the presence of PHCs that increase the resistivity. The 2D analysis revealed the presence of PHCs up to a depth of $10.0 \mathrm{~m}$ but very prominent at a depth of 5.0 which, indicated presence of PHCs in the wells. However, at a far distance, the effect of the PHCs reduced drastically. Hydro chemical results also proved the same results as that of the VES and 2D which authenticated the reliability of the method used in the study.

\section{References}

American Public Health Association [APHA] 2005 Standard Methods for the Examination of Water and Wastewater. 21st Edition, American Public Health Association/American Water Works Association/Water Environment Federation, Washington DC.

Barker RD 1981 Offset system of electrical resistivity sounding and its use with a multicore cable. Geophys. Prospect. 29: 128-143.

Bhattacharya PK and Patra HP 1968 Direct Current Electrical Sounding, Elsevier, Amsterdam.

de Castro J, Ballestreros F, Méndez A and Tarquis AM 2014 Fractal analysis of Laplacian pyramidal filters applied to 
segmentation of soil images. Sci. World J. 2014.

Clinton HI, Ujagwung GU and Horsfall $\mathrm{M}$ 2009 Evaluation of total hydrocarbon levels in some aquatic media in oil-polluted mangrove wetland in the Niger Delta, Appl. Ecol. Environ. Res. 7(2): 111-120.

Evirgen B, Onur MI, I Tuncan M and Tuncan A 2015 Determination of freezing effect on unconfined compression strength and permeability of saturated granular soils. Int J. Geomate 8(2): 1283-1287.

Federal Ministry of Environment (FMENV) 1991 Guidelines and Standards for Environmental Pollution in Nigeria. Lagos, Nigeria.

Grant NK 1971 A computation of radiometric ages from Nigeria. J. Mining and Geol. 6: 37-54.

Habberjam GM and Watkins GE 1967 The reduction of lateral effects in resistivity probing. Geophys. Prospect. 15: 221-235.

Holdway DA 2002 The acute and chronic effects of wastes associated with offshore oil and gas production on temperate and tropical marine ecological processes. Marine Pollut. Bull. 44(3): 185-203.

Ite WE, Ibok UJ, Ite MU and Petters SW 2013 Petroleum exploration and production: Past and present environmental issues in Nigeria's Niger Delta Am. J. Environ. Prot. 1(4): 78-90.

Kponee KZ, Chiger A, Kakulu II, Vorhees D and Heiger-Bernays W 2015 Petroleum contaminated water, and health symptoms: a cross-sectional pilot study in a rural Nigeria community. Environ. Health 14(1): 86.
Lindén O and Pålsson J 2013 Oil contamination in ogoniland, Niger Delta. Ambio 42(6): 685-701.

Mohamadi B, Xie Z and Liu F 2015 GIS based oil spill risk assessment model for the Niger Delta's vegetation. Nat. Environ. Pollut. Technol. 14(3): 545.

Obida CB, Blackburn GA, Whyatt JD and Semple KT 2018 Quantifying the exposure of humans and the environment to oil pollution in the Niger Delta using advanced geostatistical techniques. Environ. Int. 111: 32-42.

Ordinioha B and Brisibe S 2013 The human health implications of crude oil spills in the Niger Delta, Nigeria: An interpretation of published studies. Nigerian Med. J.: J. Nigeria Med. Assoc. 54(1): 10.

Rahaman MA 1976 Review of basement geology of Southwestern, Nigeria. In: Kogbe CA Geology of Nigeria $2^{\text {nd }}$ revised edition.

Rittmann BE 1995 Transformation of organic micropollutants by biological processes. Water Pollut. 5/5B: 31-60.

Yakubu O 2017 Addressing environmental health problems in Ogoniland through the implementation of United Nations Environmental Program Recommendations: environmental managements strategies. Environments 4(2): 28.

Yenne EY, Anifowose AYB, Dibal HU, Nimchak RN 2015 An assessment of the relationship between linearment and groundwater productivity in a part of the basement complex Southwestern Nigeria. IOSR J. Environ. Sci. Toxicol. Food Technol. 9(6): 23-35. 